\title{
Altered CD4+/CD8+ T-cell ratio in splenocytes of human T-cell leukemia virus type I Tax transgenic mice with inflammatory arthropathy
}

\author{
Takeo Ohsugi $i^{*}$, Toshio Kumasaka ${ }^{2}$ \\ From 15th International Conference on Human Retroviruses: HTLV and Related Viruses \\ Leuven and Gembloux, Belgium. 5-8 June 2011
}

Human T-cell leukemia virus type I (HTLV-1) infection in human causes an aggressive malignancy, adult $\mathrm{T}$-cell leukemia (ATL), as well as inflammatory diseases such as HTLV-1-associated myelopathy/tropical spastic paraparesis (HAM/TSP). A transgenic mouse model expressing Tax in mature thymocytes and peripheral $\mathrm{T}$ lymphocytes caused mature $\mathrm{T}$ cell leukemia resembling ATL. We also found that inflammatory arthropathy develops among Tax-expressing mice without leukemia. The pathological findings of arthropathy in Tax transgenic mice were similar to those seen in human rheumatoid arthritis or mouse models of rheumatoid arthritis, with synovial proliferation and a positive rheumatoid factor. No group differences between control mice and arthropathic mice were found in the proportion of $\mathrm{T}$ and $\mathrm{B}$ cells in spleens. The arthropathic mice showed a significantly decreased proportion of splenic CD4+ T cells, whereas the proportion of splenic CD8+ $\mathrm{T}$ cells was increased. The Th17 cells were not detected in arthropathic mice. Regulatory T cells $(\mathrm{CD} 4+\mathrm{CD} 25$ +Foxp3+) were significantly decreased and CD8+ T cells that expressed the chemokine receptor CCR4 (CD8 + CCR4+) were significantly increased in arthropathic Tax transgenic mice. The expression of tax mRNA was strong in the spleen and joints of arthropathic mice, with a 40-fold increase compared with healthy-transgenic mice.Tax transgenic mice develop rheumatoid-like arthritis; however, splenic T-cell subsets in these mice was completely different from other commonly used animal models of rheumatoid arthritis. The crucial Tcell subsets in these mice appear to resemble those in

\footnotetext{
* Correspondence: ohsugi@gpo.kumamoto-u.ac.jp

'Institute of Resource Development and Analysis, Kumamoto University, 2-21 Honjo, Kumamoto 860-0811, Japan

Full list of author information is available at the end of the article
}

HAM/TSP patients rather than those in rheumatoid arthritis patients.

\section{Author details}

'Institute of Resource Development and Analysis, Kumamoto University, 2-21 Honjo, Kumamoto 860-0811, Japan. ${ }^{2}$ Department of Pathology, Japanese Red Cross Medical Center, 4-1-22 Hiroo, Shibuya-ku, Tokyo 150-8935, Japan.

Published: 6 June 2011

\section{doi:10.1186/1742-4690-8-S1-A2}

Cite this article as: Ohsugi and Kumasaka: Altered CD4+/CD8+ T-cell ratio in splenocytes of human T-cell leukemia virus type I Tax transgenic mice with inflammatory arthropathy. Retrovirology 20118 (Suppl 1):A2.

Submit your next manuscript to BioMed Central and take full advantage of:

- Convenient online submission

- Thorough peer review

- No space constraints or color figure charges

- Immediate publication on acceptance

- Inclusion in PubMed, CAS, Scopus and Google Scholar

- Research which is freely available for redistribution

Submit your manuscript at www.biomedcentral.com/submit
() Biomed Central

\section{() Biomed Central}

